\title{
Photo Studio Booking Information System (Case Study: Reflection Photography Yogyakarta)
}

\author{
Sri Haryati ${ }^{1)}$, Chanifah Indah Ratnasari ${ }^{2}{ }^{2}$ \\ Department of Informatics, Faculty of Industrial Technology, Universitas Islam Indonesia \\ Kaliurang Street KM. 14.5, Sleman, Yogyakarta, 55584, Indonesia ${ }^{1)}$ ) \\ E-Mail:15523238@students.uii.ac.id ${ }^{1)}$, chanifah.indah@uii.ac.id ${ }^{2)}$ \\ * corresponding author
}

\begin{abstract}
There is no system used for booking a photo studio, making it quite difficult for customers to book a photo studio at Reflection Photography Yogyakarta. To book the photo studio, clients have to come in person, through WhatsApp chat, or by phone call. However, the studio is often slow in replying to WhatsApp chats from customers. Additionally, the recording of ordering data is still done manually using paper and transaction reports made using Microsoft Excel. The purpose of this research is to develop an information system to overcome these problems. The system built is web-based and uses the prototyping method. This system was tested by two tests, black-box and usability testing. For black-box test results, all the features tested show conformity as expected. As for the usability test results, all tested technical aspects showed $94.29 \%$ that the system considered as easy to use by users.
\end{abstract}

Keywords: Photo Studio Information System, Photo Studio Booking System, Prototyping Method, Black Box Testing, Usability Testing

\section{Introduction}

Photography is a medium that can be used to document an important moment or event (Sudarma, 2014). According to (Bull, 2010), the word photography comes from Greek, namely "photo" from the word "phos" which means light and "graphy" from the word "graphe" which means writing or image. Therefore, the literal meaning of photography is writing or drawing with light.

Photography first entered Indonesia by the Dutch, namely by Juriaan Munich in 1841 (Alfarizhi, 2017). At that time, the photo was still in monochrome, or black-and-white. As time goes by, color photos were first introduced by James Clerk Maxwell in 1861 (Drozdenko, 2012). In the 19th century, studio photography became known (Shofi, 2014). A photo studio is a room that is specially designed by considering various aspects such as lighting, background, and various kinds of settings that can support the shooting process.
The use of photo studio services is quite popular, especially in capturing important moments such as graduation, maternity photos, pre-wedding, wedding, and other important moments. However, based on a survey of 30 photo studio service users, there are several problems experienced by customers related to ordering photo studio services, among them namely, the first: there is no system that can facilitate the photo studio ordering process because orders can only be made by coming directly to the studio, via WhatsApp, or by phone call. The second: the limitations of customers in finding information about the packages offered, and third: the studio's response is slow. Based on the same survey results, the list of photo studios in Yogyakarta recommended by customers with the highest ranking is Reflection Photography.

Reflection Photography is a professional photo studio service provider located in Yogyakarta, precisely at Padjajaran 
Street number 2, Manggung, Caturtunggal, Depok, Sleman, Special Region of Yogyakarta. Services offered by Reflection Photography are Graduation and Family photos, Group, Personal, Couple, Baby and Maternity, Product Photography, Architectural Photography, Outdoor Documentation, Pre-wedding and Wedding. Based on the interviews conducted with Reflection Photography regarding the ongoing business process and their mechanisms for recording and managing data, some information was obtained.

For example, to place an order or to find information related to services offered, customers must come directly to the studio, contact via WhatsApp or by a phone call. Social media that they used, namely Instagram, is only used as promotional media and provides photo references. In managing data and making transaction reports, Reflection Photography Yogyakarta still uses manual methods by recording order data on paper and making transaction reports using Microsoft Excel. The absence of a system that is used to facilitate ordering a photo studio as well as recording and producing reports makes business processes running less efficient. Therefore, it is necessary to build an information system to overcome these problems.

The rest of this paper is organized as follows. Section 2 describes related works. Section 3 describes the methodology. Section 4 describes the results of this research. Finally, the concluding remarks are described in section 5 .

\section{Related Works}

A study often has similar or related studies that preceded it, likewise with this research. Similar research from this research are (Nugroho, 2015), (Sinaga \& Hasti, 2018), (Putra, 2012), and (Iswandaru, 2014).

Nugroho (2015) built a web-based photography service ordering information system at Karma Kreatif Semarang. Sinaga \& Hasti (2018) built a photo studio ordering information system at Fakhri Almubarok
Studio Bengkulu. Putra (2012) built a webbased ordering system at Studio Kreasindo Palembang. Iswandaru (2014) analyzed and designed a web-based photography service ordering information system in Cleo Photography. In addition to similar studies that have been mentioned, some websites serve as reference material in this study, namely kikiphotostudio.com and alvinstudio.co.id. The summary of system features from the above studies is shown in Table 1 .

Table 1. Summary of System Features from Related Works

\begin{tabular}{lllllll}
\hline \multicolumn{1}{c}{ Feature } & $\mathrm{a}$ & $\mathrm{b}$ & $\mathrm{c}$ & $\mathrm{d}$ & $\mathrm{e}$ & $\mathrm{f}$ \\
\hline $\begin{array}{l}\text { Account } \\
\text { Registration }\end{array}$ & - & - & - & $\checkmark$ & $\checkmark$ & - \\
\hline $\begin{array}{l}\text { Package } \\
\text { Management }\end{array}$ & $\checkmark$ & $\checkmark$ & $\checkmark$ & $\checkmark$ & $\checkmark$ & $\checkmark$ \\
\hline $\begin{array}{l}\text { Package } \\
\text { Type } \\
\text { Management }\end{array}$ & $\checkmark$ & $\checkmark$ & $\checkmark$ & $\checkmark$ & $\checkmark$ & $\checkmark$ \\
\hline $\begin{array}{l}\text { Photo studio } \\
\text { booking }\end{array}$ & $\checkmark$ & - & $\checkmark$ & $\checkmark$ & $\checkmark$ & $\checkmark$ \\
\hline $\begin{array}{l}\text { Payment } \\
\text { confirmation }\end{array}$ & - & - & $\checkmark$ & $\checkmark$ & - & $\checkmark$ \\
\hline $\begin{array}{l}\text { Customer } \\
\text { Data } \\
\text { Recording }\end{array}$ & - & - & $\checkmark$ & - & - & $\checkmark$ \\
\hline $\begin{array}{l}\text { Transaction } \\
\text { Report }\end{array}$ & - & - & - & $\checkmark$ & - & - \\
\hline $\begin{array}{l}\text { Information: } \\
\text { Mformatk }\end{array}$ & & & & & \\
\hline
\end{tabular}

a. kikiphotostudio.com

b. alvinstudio.co.id

c. (Nugroho, 2015)

d. (Sinaga \& Hasti, 2018)

e. (Putra, 2012)

f. (Iswandaru, 2014)

The system developed in this research contains all the features listed in Table 1. Other advantages of this system are:

a. clients can change the photo shooting schedule;

b. clients can increase the number of people from the maximum number of people on the package offered at the time of placing an order;

c. the studio can see the graph of order data recapitulation and income. 


\section{Methodology}

In this study, the system to be built is web-based and developed using the prototyping method. Prototyping is a system development technique that uses a prototype to describe the system so that the user or system owner has an overview of system development to be done (Mulyani, 2016). There are two types of prototypes, the evolutionary prototype and the requirement prototype. In this research, the type used is the requirement prototype. In this type, the developer built the prototype by defining system functions and procedures in which the user or system owner cannot define the system. This type's weakness is that the user or owner of the system can continuously increase the system's complexity until the system becomes very complex. Some of the advantages of this type are: 1) the user or owner of the system is involved in the development so that the possibility of misunderstanding in the system can be minimized, 2) the resulting system quality is good. The steps taken in this study are shown in Figure 1.

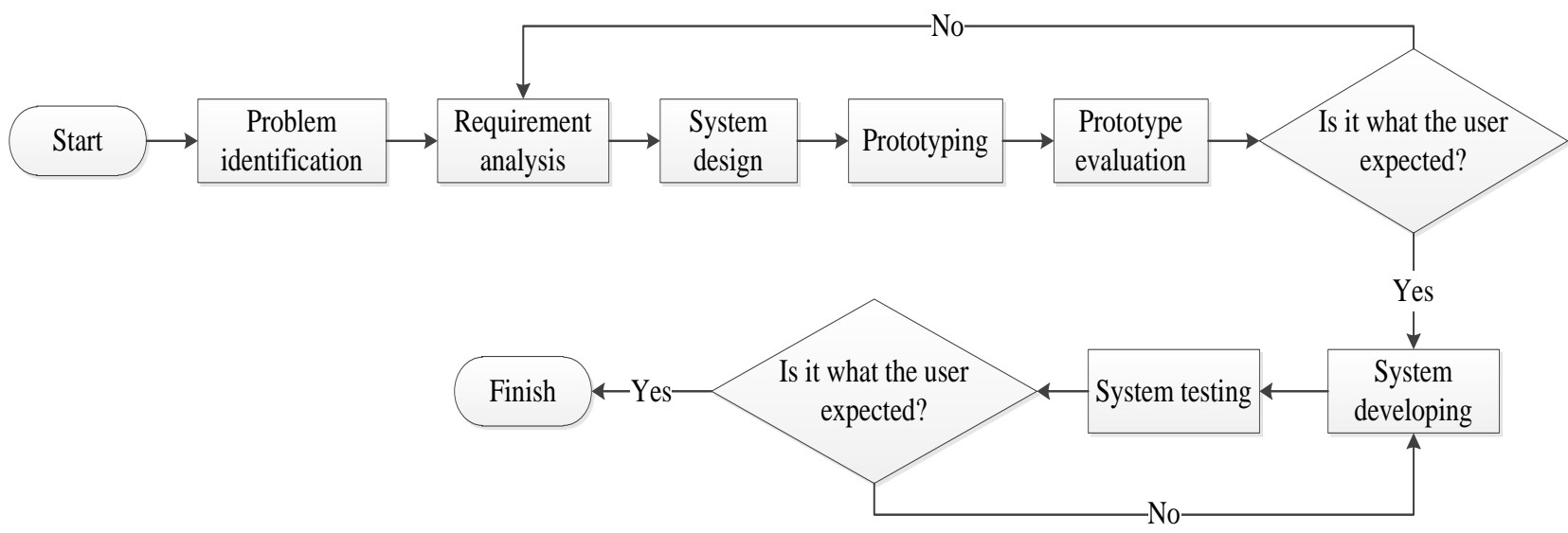

Figure 1. Research Steps

\subsection{Problem Identification}

This stage is used to identify problems and gather various information related to the case study being undertaken.

\subsubsection{Distribute questionnaires}

The questionnaire was filled out by 30 photo studio service users in Yogyakarta. Based on the results of the questionnaire, there were several obstacles in ordering a photo studio, namely:

d. reservations can only be made by visiting the photo studio, contacting via WhatsApp, or by phone;

e. response from the studio is slow;

f. limitations in obtaining information about photo packages along with descriptions and prices;

g. difficulty when rescheduling the shooting date; h. could not get a photo schedule according to the desired date;

i. no system facilitates selecting packages, studios, and online booking features that make the booking still done manually.

Based on the results of the questionnaire, some of the system features desired by customers are features that facilitate package selection along with descriptions and prices, studio selection, background selection, photoshoot date selection, sample photos of each package, payment confirmation, photoshoot rescheduling, order detail notification, and payment status notification.

\subsubsection{Observation.}

Researchers made observations at Reflection Photography Yogyakarta. At the time of observation, researchers conducted observations from the process of ordering, 
payment to the process of booking recording made by the admin. Based on these observations, the researcher obtained information that the recording of booking was still done manually using paper. After being recorded using paper, the admin will re-record the data and create a transaction report using Microsoft Excel.

\subsubsection{Interview}

Interviews were conducted with the supervisor of Reflection Photography Yogyakarta. The results of the interview are information about: 1) photo packages and the types of packages available in Reflection Photography, 2) the flow of photo studio booking, either for those that come directly to the studio, via WhatsApp chat, or phone call, $3)$ the photo studio booking recording mechanism by the admin, 4) payment process, 5) mechanism to reschedule the photoshoot date, up to 6) customers take a photoshoot.

\subsubsection{Literature Study}

Researchers are looking and reviewing the literature related to the photo studio booking information system. Literature studies are obtained from journals, articles, books, and other information used as a reference source in this research. Based on the literature discussed in section 2, as well as the identification of the problems carried out, it is determined what features will be built.

\subsection{Prototyping Iteration}

Based on the problem identification stage, requirement analysis is carried out to build a prototype. The requirement analysis includes analyzing the photo studio booking flow, user analysis, analysis of input requirements, processes, outputs, interfaces, software, and hardware. Furthermore, the system design is carried out as a reference in making prototypes. After the prototype is finished, the prototype is evaluated.

Prototype evaluation carried out by manager and supervisor of Reflection Photography Yogyakarta and seven potential users of the system. Prototype evaluation is done by the user doing the prototype simulation of each iteration. In the fourth iteration of the prototype evaluation, Reflection Photography and potential system users state that the prototype conforms with what is required.

\subsection{System Developing}

The system is built based on the results of the final evaluation of the prototype. It is built with the PHP programming language, Codeigniter framework, CSS framework using Bootstrap and MySQL database.

\subsection{System Testing}

In this study, two types of testing were carried out: black-box and usability testing.

\subsubsection{Black box testing}

Black box testing is a software testing technique that focuses on the software's functional specifications (Jaya, 2018). This test is performed to find functionality errors such as missing or incorrect functions, interface design errors, data structure errors or external database access, performance errors, and initialization and termination errors (Febiharsa, Sudana, \& Hudallah, 2018).

\subsubsection{Usability testing.}

There are several international standards related to usability in information technology, one of which is ISO 9241-11 (Marghescu, 2009). In this ISO, one of the components of usability is satisfaction. The definition of satisfaction in this ISO is freedom from discomfort and a positive attitude towards the product use (International Organization for Standardization, 1998). In other words, satisfaction is the comfort and acceptability of using the system (Seffah, Donyaee, Kline, \& Padda, 2006). Usability testing conducted in this study is used to determine the level of ease and convenience when users interact with the system. Testers tried the system directly, then asked to fill out a questionnaire. The questionnaire in this study was adapted from (Sauro, 2015) - the usability section and (Henriyadi \& Mulyati, 2014). 


\section{Results}

The overall functionality of the system is depicted in Figure 4. There are three actors in the system, namely admin, member, and user. To be able to perform activities as admin and member, actors must $\log$ in first. The explanation of each use case can be seen in Table 2. It can be seen that the system features of this study are more than the features of similar research systems (Table 1). So we can say that this system has a novelty value compared to systems from similar studies.

The user must be registered as a member first to be able to book a photo studio.
Booking is made by selecting the photo package and package type. Furthermore, the member is asked to fill out a form that contains the date of the photoshoot, additional people (optional), which photo studio the user wanted to use and the background to be used. The page for selecting photo package and package type, as well as the order form, can be seen in Figure 2 and Figure 3. Once the user submitted the order form, the system will send an email notification regarding the details of the order that has been made.

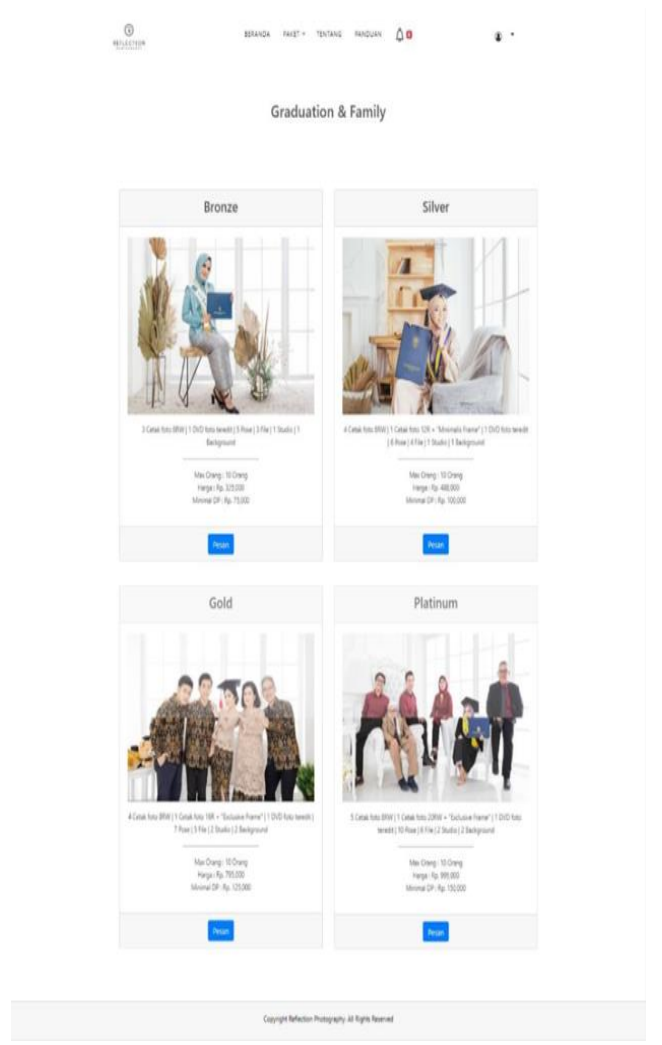

Figure 2. The Page for Selecting Photo Package and Package Type

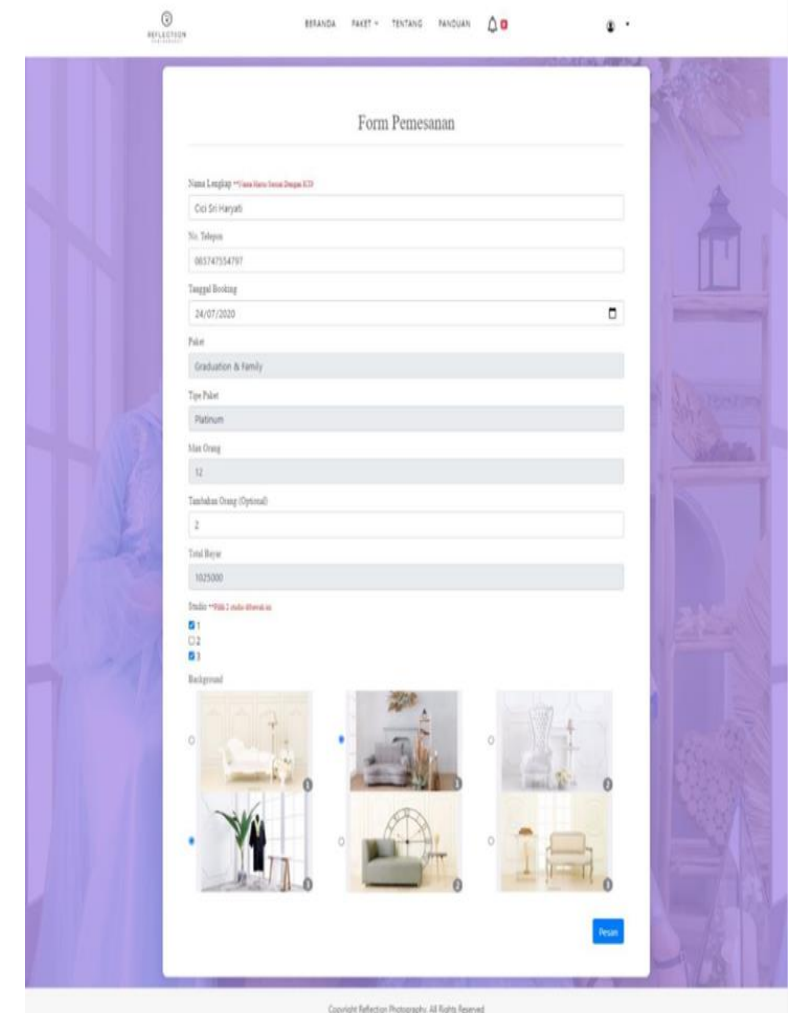

Figure 3. Order Form Page 
Teknoin Vol. 27, No. 1, March 2021:47-57

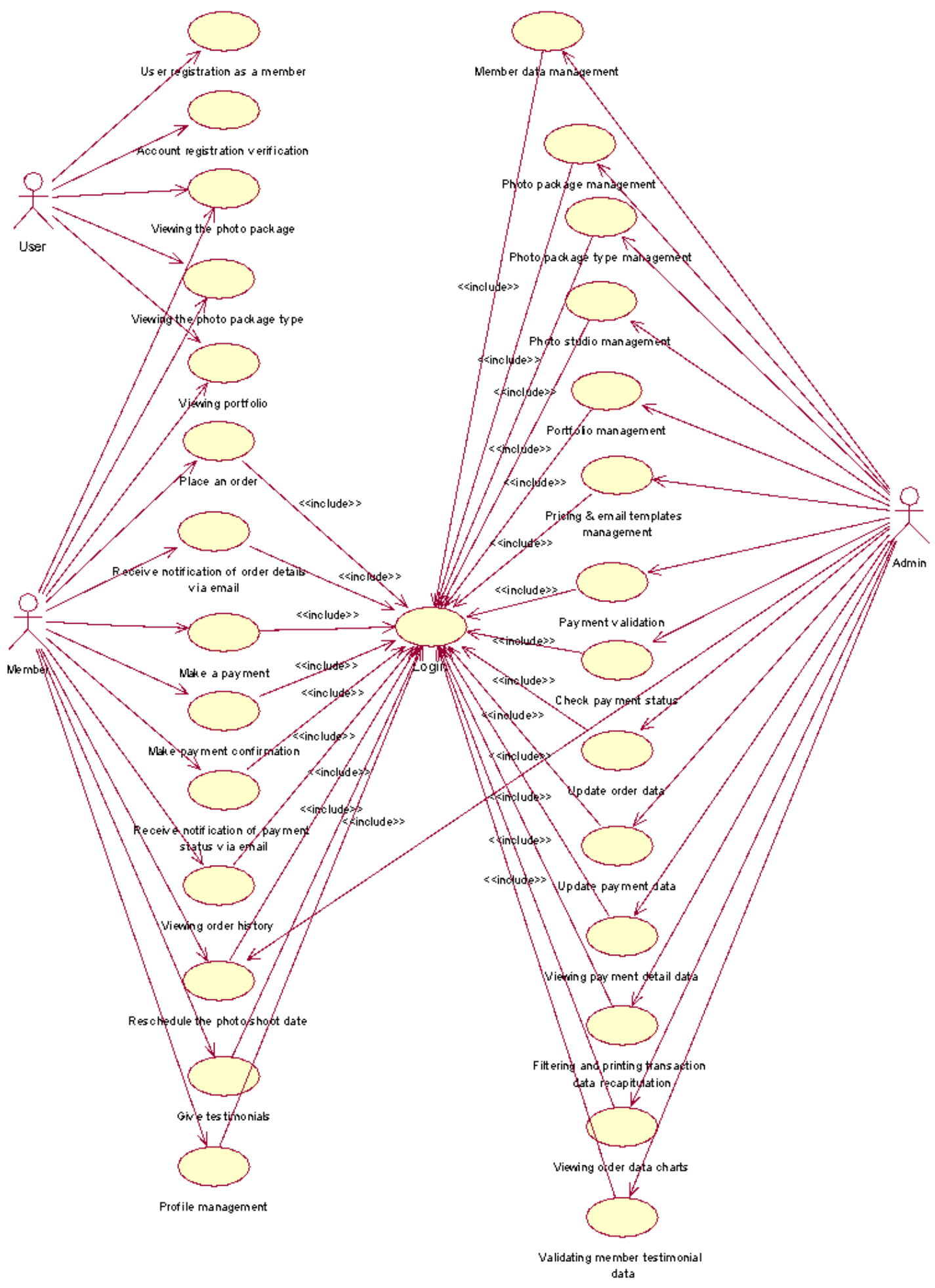

Figure 4. The Use Case Diagram 
Table 2. The Use Case Explanation

\begin{tabular}{|c|c|c|c|}
\hline Number & Use case & Description & Actor \\
\hline 1 & $\begin{array}{l}\text { User registration as a } \\
\text { member }\end{array}$ & $\begin{array}{l}\text { User register as a member of Reflection } \\
\text { Photography Yogyakarta to book the photo } \\
\text { studio. }\end{array}$ & User \\
\hline 2 & $\begin{array}{l}\text { Account registration } \\
\text { verification }\end{array}$ & $\begin{array}{l}\text { The user receives an email containing a } \\
\text { verification link account. If it has been verified, } \\
\text { the user can log in to the system. }\end{array}$ & User \\
\hline 3 & $\begin{array}{l}\text { Viewing the photo } \\
\text { package }\end{array}$ & $\begin{array}{l}\text { Users can view photo packages offered by } \\
\text { Reflection Photography Yogyakarta. }\end{array}$ & User dan Member \\
\hline 4 & $\begin{array}{l}\text { Viewing the photo } \\
\text { package type }\end{array}$ & $\begin{array}{l}\text { Users can view the type of photo packages } \\
\text { available in Reflection Photography } \\
\text { Yogyakarta. }\end{array}$ & User dan Member \\
\hline 5 & Viewing portfolio & $\begin{array}{l}\text { Users can view the portfolio of Reflection } \\
\text { Photography Yogyakarta. }\end{array}$ & User dan Member \\
\hline 6 & Place an order & $\begin{array}{l}\text { Member book a photo studio by selecting a } \\
\text { photo package, package type, date of a } \\
\text { photoshoot, additional number of people } \\
\text { (optional), photo studio, and background to be } \\
\text { used. }\end{array}$ & Member \\
\hline 7 & $\begin{array}{l}\text { Receive notification of } \\
\text { order details via email }\end{array}$ & $\begin{array}{l}\text { Member receives notification booking details } \\
\text { via email. }\end{array}$ & Member \\
\hline 8 & Make a payment & $\begin{array}{l}\text { Member makes a payment for the order that has } \\
\text { already been done. Payment can be made with } \\
\text { a down payment or in full with a time limit of } \\
1 \times 24 \text { hours. }\end{array}$ & Member \\
\hline 9 & $\begin{array}{l}\text { Make payment } \\
\text { confirmation }\end{array}$ & $\begin{array}{l}\text { Member confirms payment by attaching proof } \\
\text { of payment. }\end{array}$ & Member \\
\hline 10 & $\begin{array}{l}\text { Receive notification of } \\
\text { payment status via } \\
\text { email }\end{array}$ & $\begin{array}{l}\text { Member gets notification of payment status via } \\
\text { email if confirmation of the payment made has } \\
\text { been validated by the admin. }\end{array}$ & Member \\
\hline 11 & Viewing order history & $\begin{array}{l}\text { Member can view order history that has been } \\
\text { made along with the status of each order. }\end{array}$ & Member \\
\hline 12 & $\begin{array}{l}\text { Reschedule the } \\
\text { photoshoot date }\end{array}$ & $\begin{array}{l}\text { Member can reschedule photoshoot date before } \\
\mathrm{D}-3 \text {. If rescheduling is done } \mathrm{D}-3 \text { to } \mathrm{D}+3 \text {, then } \\
\text { reschedule conducted by admin. }\end{array}$ & Admin dan Member \\
\hline 13 & Give testimonials & $\begin{array}{l}\text { Members can provide testimonials on } \\
\text { Reflection Photography. Testimonials can be } \\
\text { given if the order has the status "Diambil" } \\
\text { (taken), which means the order has been } \\
\text { completed (in this case, the photo has been } \\
\text { taken). }\end{array}$ & Member \\
\hline 14 & Profile management & $\begin{array}{l}\text { Member can change the name, phone number, } \\
\text { address, and password for the account that has } \\
\text { been created. }\end{array}$ & Member \\
\hline 15 & $\begin{array}{l}\text { Member data } \\
\text { management }\end{array}$ & $\begin{array}{l}\text { Admin can view data of members who have } \\
\text { registered an account, both verified and } \\
\text { unverified accounts. Admin can delete the data } \\
\text { member that has not been verified. }\end{array}$ & Admin \\
\hline
\end{tabular}


16 Photo package management

17 Photo package type management

18 Photo studio management

19 Portfolio management

20 Pricing \& email templates management

21 Payment validation

22 Check payment status

23 Update order data

24 Update payment data Viewing payment detail data

26 Filtering and printing transaction data recapitulation

27 Viewing order data charts

28 Validating member testimonial data
Admin can add, update, delete and search photo

Admin package data.

Admin can add, update, delete and search for the photo package type.

Admin can manage (add, update, delete and search) studio data and studio detail data.

Admin can add, update, delete and search portfolio data.

Admin can add, modify and search for data settings, namely price settings (which includes the cost of adding people, poses, and files) and email template settings (which includes account registration verification email templates, order details, and payments).

Admin validate payment made by the member. Admin checks the payment status of the order, whether the member has made a payment or not.

Admin can modify the order data if there is an update needed in the order. The order's data that can be modified include the addition of the number of poses and the number of files.

Admin confirms the payment, whether the payment made by the member is valid or not.

Admin

Admin the member.

Admin can filter and print a summary of

Admin transaction data per day, week, month, or year.

Admin can view a graph of order data recapitulation per month and a revenue graph per three months.

Admin can view, confirm and delete testimonial data written by members. Testimonials will appear on the website if the testimonial status has been confirmed by the admin. 
Booking which has been done can be seen in the order history page of the member. On that page, booking data has several statuses. The initial status after a member places an order is "Pending". If the member has made payment and payment confirmation, also has been verified by the admin, the order status will change according to the type of payment that has been made, namely:

- If a member makes a down payment, the order status will change to "DP" (short for the Down Payment) and repayment can be made on the spot at the cashier on the day of the photoshoot.

- If the member makes full payment, the order status will change to "Proses" (process).

- If the member does not make a payment within $1 \times 24$ hours from the time of order, the order will be automatically canceled, and the order status changes to "Cancel".

When the photoshoot has been carried out and the photos are already printed and ready to be taken, the order status will change to "Selesai". Member will receive a notification in the system that the printed photo is ready to be taken. If the member has taken the printed photo, the order status will be changed to
"Diambil" (taken), and the member can fill out the testimonial form provided.

There are two tests in this study, namely black box testing and usability testing. There are 27 scenarios to be tested as a user and member actor, and 67 scenarios to be tested as an admin actor. The test results are showing that the system provides output as expected.

Usability testing was carried out by the manager and supervisor of Reflection Photography Yogyakarta and seven potential users of the system in the age range 22-35 years. The questionnaire given to respondents is a questionnaire containing open questions on respondent's characteristics (name, gender, and age) and closed questions (using a Likert scale with a range of 1 to 5). Usability test results can be seen in Table 3 and Table 4.

Based on the five aspects tested on seven potential users of the system, getting an average result of $94.10 \%$. Meanwhile, based on the ten aspects tested on two people from Reflection Photography, the average result was $94.49 \%$. So the overall average of usability testing is $94.29 \%$. All tested technical aspects show more than $75 \%$ result, which means the users considered satisfied with the system's ease of use.

Table 3. Usability Testing on Seven Potential Users of The System

\begin{tabular}{clll}
\hline Number & \multicolumn{1}{c}{ Aspect } & Result & Information \\
& & & \\
\hline 1 & Administration and Interface & $93.33 \%$ & Accepted \\
2 & Selection of Package and Package Type & $93.33 \%$ & Accepted \\
3 & Booking & $94.29 \%$ & Accepted \\
4 & Order History & $94.29 \%$ & Accepted \\
5 & Guide & $95.24 \%$ & Accepted \\
\hline
\end{tabular}


Table 4. Usability Testing on Two People in Reflection Photography Yogyakarta

\begin{tabular}{clcc}
\hline Number & \multicolumn{1}{c}{ Aspect } & Result & Information \\
\hline 1 & Administration and Interface & $88.57 \%$ & Accepted \\
2 & Grafik Data Reservasi dan Pendapatan & $90.00 \%$ & Accepted \\
3 & Member Data Management & $90.00 \%$ & Accepted \\
4 & Photo Package and Package Type Data & $96.00 \%$ & Accepted \\
& Management & $96.00 \%$ & Accepted \\
5 & Portfolio Data Management & $96.67 \%$ & Accepted \\
6 & Filter and Print Transaction Reports & $95.00 \%$ & Accepted \\
7 & Booking Data Management & $96.00 \%$ & Accepted \\
8 & Studio Data and Studio Detail Management & $100.00 \%$ & Accepted \\
9 & Testimonial Data Management & $96.67 \%$ & Accepted \\
\hline
\end{tabular}

\section{Conclusion}

The photo studio booking information system was built to facilitate ordering a photo studio, in this case, Reflection Photography Yogyakarta, which was done by coming directly to the studio, via WhatsApp chat, or by phone call. The system built also makes it easier for Reflection Photography Yogyakarta to manage data and create transaction reports, which initially used paper to record ordering data and processed with Microsoft Excel. This system can also help customers get information related to photo studios, make it easier for customers to confirm payment, and reschedule the photoshoot date. Moreover, this system can also accommodate booking with an additional number of people if it exceeds people's capacity in the photo package.

The system built is web-based using the prototyping method. This system has 28 system functionalities with three actors, namely admin, member, and user. Based on the testing phase, the system works as expected, and the user accepts it in terms of ease of use. Future research will be conducted to expand the system's functionalities or features, such as a financial management feature, storing photoshoot results into the user profile, ordering outdoor photoshoots, and other features based on the photo studio's business process.

\section{References}

Alfarizhi, M. A. (2017). Perancangan Buku Tutorial Olah Kebugaran Tubuh dengan Teknik Story Photography Sebagai Upaya Menyadarkan Pola Hidup Sehat. Surabaya: Institut Bisnis dan Informatika STIKOM Surabaya.

Bull, S. (2010). Photography. New York: Routledge.

Drozdenko, D. A. (2012). Photography Is A Pure Miracle. 09 September 2020. https://essuir.sumdu.edu.ua/bitstreamdownload/123456789/26054/1/Drozden ko.pdf

Febiharsa, D., Sudana, I. M., \& Hudallah, N. (2018). Uji Fungsionalitas (Blackbox Testing) Sistem Informasi Lembaga Sertifikasi Profesi (SILSP) Batik dengan AppPerfect Web Test dan Uji Pengguna. JOINED Journal (Journal of Informatics Education), Vol.1, No.2, 117-126.

Henriyadi, \& Mulyati, R. (2014). Usability Testing Sistem Informasi: Studi Kasus Pada Aplikasi Repositori Publikasi Badan Penelitian dan Pengembangan Pertanian. Jurnal Perpustakaan Pertanian, Vol.23, No.2, 54-63.

International Organization for Standardization. (1998). ISO 9241-11. Ergonomic requirements for office work with visual display terminals (VDTs) Part 11: Guidance on usability. 
Iswandaru. (2014). Perancangan Sistem Informasi Pemesanan Jasa Fotografi Berbasis Web Pada Cleo Photography. Yogyakarta: Universitas Amikom Yogyakarta.

Jaya, T. S. (2018). Pengujian Aplikasi dengan Metode Blackbox Testing Boundary Value Analysis (Studi Kasus: Kantor Digital Politeknik Negeri Lampung). Jurnal Informatika: Jurnal Pengembangan IT (JPIT), Vol.03, No.02, 45-48.

Marghescu, D. (2009). Usability Evaluation of Information Systems: A Review of Five International Standards. Dalam Information Systems Development (pp. 131-142). Boston, MA: Springer US.

Mulyani, S. (2016). Metode Analisis dan Perancangan Sistem. Bandung: Abdi Sistematika.

Nugroho, R. A. (2015). Sistem Informasi Pemesanan Jasa Fotografi Berbasis Web Pada Karma Kreatif Semarang. Semarang: Universitas Dian Nuswantoro.
Putra, J. C. (2012). Aplikasi Pemesanan Pada Studio Kreasindo Palembang Berbasis Web. Palembang: STMIK Global Informatika MDP.

Sauro, J. (2015). SUPR-Q: A Comprehensive Measure of the Quality of the Website User Experience. Journal of Usability Studies, Vol.10, No.2, 68-86.

Seffah, A., Donyaee, M., Kline, R. B., \& Padda, H. K. (2006). Usability measurement and metrics: A consolidated model. Software Quality Journal, Vol.14, 159-178.

Shofi, M. (2014). Desain Interior Studio Adventur Canon EOS IDX Jawa Dekonstruksi Style di Surabaya. Surabaya: Institut Teknologi Sepuluh Nopember.

Sinaga, R. S., \& Hasti, N. (2018). Sistem Informasi Pemesanan Studio Foto Pada Fakhri Almubarok Studio. Bandung: Universitas Komputer Indonesia.

Sudarma, I. K. (2014). Fotografi. Yogyakarta: Graha Ilmu. 